\title{
EVALUATION OF CLINICAL PERFORMANCE AND SUCCESS OF FUJI II AND FUJI IX IN RESTORING OCCLUSAL CARIES OF PRIMARY MOLARS OVER A ONE YEAR FOLLOW UP: A RANDOMIZED CLINICAL TRIAL
}

\author{
Manal A. El Sayed*, Walid A. Fouad* and Hany M. Saber**
}

\begin{abstract}
Introduction: Dental practitioners frequently face a notable challenge in selecting an ideal restorative material. Glass ionomer cement (GIC) has been a frequently used material as a substitute to amalgam in restoring primary dentition.
\end{abstract}

Aim of the study: To clinically evaluate GC Fuji II LC (Light-Cured, Resin-Reinforced Glass Ionomer Restorative) and GC Fuji IX GP EXTRA (Packable Glass Ionomer) when used to restore occlusal caries in lower second primary molars.

Materials and Methods: Seventy-six molars in 38 children were included in this study. Inclusion criteria included patients; (1) Free from any medical conditions. (2) Aged 5-7 years old. (3) Reported with bilateral restorable decayed second primary molars with simple occlusal decay. (4) Clinically; no signs of irreversible pulpitis. Split-mouth technique was used and a single operator performed all restorations. Examined restorative materials were randomly allocated to either side of the mouth. Cavities were prepared in the utmost conservative manner. Both Fuji II and Fuji IX were prepared according to manufacturers' instructions. Clinical assessment was performed after 3, 6, 9 and 12 months according to United States Public Health Services (USPHS) evaluation criteria and rating system. Statistical Analyses included Wilcoxon signed-rank test as well as Friedman's test followed by Dunn's test.

Results: Among the treated 38 subjects; there were 18 boys (47.4\%) and 20 girls $(52.6 \%)$. Mean \pm standard deviation values for age were $5.7 \pm 0.8$ years old with a minimum of 5 and a maximum of 7 years old. After 12 months, a statistically significant difference was noted between marginal adaptation, anatomic form, secondary caries and marginal discoloration scores in the two materials.

Conclusions: Fuji II and Fuji IX showed comparable marginal adaptation. Fuji II restorations showed better results regarding anatomic form, secondary caries and marginal discoloration when compared to Fuji IX.

*Associate Professor- Pediatric Dentistry and Dental Public Health- Faculty of Dentistry- Cairo University.

**2ecturer- Pediatric Dentistry and Dental Public Health- Faculty of Dentistry- Cairo University. 


\section{INTRODUCTION}

Dental caries is a major worldwide dental health issue affecting about $50 \%$ of children less than 12 years old. (1) Children suffering from dental caries often complain from pain, difficulty in eating and sleeping as well as poor growth and development. ${ }^{(2,3)}$

Dental practitioners frequently face a notable challenge in selecting an ideal restorative material. Factors that can be taken into consideration during making such a decision include; patient's caries risk assessment, oral hygiene, type of dentition, ability to cooperate, expected parental compliance and commitment of timely recall. ${ }^{(4)}$

Survival of dental restorations is regulated by various factors as; patient's age, extent of caries, type of tooth as well as its position in dental arch, experience of practitioner and properties of used restorative material. ${ }^{(5)}$

Glass ionomer cement (GIC) has been a frequently used material as a substitute to amalgam in restoring primary dentition. ${ }^{(6,7)}$ It is a fluoride releasing salt which is formed by chemical reaction between a polyalkenoic acid and an aluminumcontaining glass. ${ }^{(8)}$

Glass ionomer cement was developed by Wilson and Kent in 1972. ${ }^{(9)}$ This material possesses several advantages such as: fluoride release, ability to recharge when exposed to fluoride rich media, physicochemical bonding to tooth structure and retaining expansion coefficient comparable to tooth structure. In contrast, GIC has some disadvantages such as: being brittle, lacking strength along with poor resistance to wear on occlusal surfaces. ${ }^{(10-18)}$

Simmons, $1983^{(19)}$ used combination of alloy powder with GIC to eliminate such disadvantages and revealed clinically successful results. However, Bilgin et al. ${ }^{(20)}$ assessed clinical success rates of combining amalgam powder with glass ionomer and GIC restorations in deciduous teeth and showed no significant difference by the end of six months.
In mid-1980's, cements derived from sintering silver particles at high temperature were based on conventional GICs. ${ }^{(21,22)}$ Further, clinical studies showed that mean survival of glass cement restorations -especially in class II restorations of primary molars- was not superior to that of conventional GICs. ${ }^{(17,6,23)}$ Nevertheless, Kilpatrick et al. ${ }^{(23)}$ detected significantly better results in conventional glass ionomer (77\%) compared to cement material (59\%) after 2.5 years. In general, glass cement materials had displayed lower clinical success rates in comparison to other restorative materials.

In early 1990's, high-viscosity GICs were developed to be utilized in atraumatic restorative treatment. Some studies reported that abrasion resistance and flexural strength of high-viscosity GICs were higher than those of conventional glass ionomer and GIC. (24-27)

Further, Lo et al. ${ }^{(28)}$ displayed 24 months success rates of atraumatic restorative treatment in primary teeth restored with highly viscous GIC (Fuji IX, GC, Japan) of $92 \%$ and $75 \%$ in class I and II restorations respectively. Moreover, Hickel \& Manhart (6) reported that the success rates of high viscosity glass ionomer cements were $94 \%$ and $72 \%$ after 12 and 24 months respectively. Likewise, Frankenberger et al. ${ }^{(29)}$ recommended using high-viscosity GICs in restoring class I and II restorations in deciduous molars.

The aim of our study was to clinically evaluate GC Fuji II LC (Light-Cured, Resin-Reinforced Glass Ionomer Restorative) and GC Fuji IX GP EXTRA (Packable Glass Ionomer) restorative materials when used to restore occlusal caries in lower second primary molars.

\section{MATERIAL AND METHODS}

\section{Subjects}

Seventy-six lower second primary molars in 38 children were included in this study. Children were selected from the outpatient clinics of Pediatric Dentistry and Dental Public Health DepartmentFaculty of Dentistry- Cairo University. The study 
was approved by the Ethical Committee and an informed consent was obtained from each parent.

\section{Sample size calculation:}

Based upon the results of Hübel \& Mejàre ${ }^{(30)}$ and using an alpha $(\alpha)$ level of 0.05 as well as Beta ( $\beta$ ) level of 0.2 i.e. power $=80 \%$. The minimum estimated sample size was 38 subjects. Sample size calculation was performed using $\mathrm{G}^{*}$ Power Version 3.1.9.2.

\section{Criteria of selection:}

Treated patients were selected according to the following inclusion and exclusion criteria:

\section{Inclusion criteria:}

1. Patients apparently healthy and free from any medical conditions.

2. Patients aged from 5-7 years old.

3. Patients had bilateral restorable decayed second primary molars with simple occlusal decay.

4. Clinically; carious lesions showing no signs of irreversible pulpitis; spontaneous pain, pain on percussion or mobility were included shown in Figure (1).

\section{Exclusion criteria:}

1. Patients presented with unrestorable carious lower second primary molar(s).

2. Patients presented with carious lower second primary molar(s) showing soft tissue abscess; sinus tract or fistula or any signs of pulp necrosis.

3. Radiographically; carious lower second primary molar(s) presented with root resorption, or periapical radiolucency were excluded.

\section{Methods:}

A split-mouth technique was used in the current study. A single operator performed all the restorations. Examined restorative materials were randomly allocated to either side of the mouth.

\section{Randomization:}

Using 4 times folded papers in which one of the tested materials was written (38 paper for each material) and put in closed white envelops (38 envelops in each one a folded paper of each tested material was placed), the selected matched bilateral carious second primary molars were randomly allocated to one of the tested materials. When guardians agreed for their child to participate in the trial, an envelope was drowned and patient personal data was written on it. At the time of treatment of the first tooth in each patient, one of the folded papers was taken from the envelope and the type of GIC was recorded. Both participants and assessors were blind to the type of materials used in each molar.

\section{Technique employed:}

Selected molars were anesthetized and isolated using rubber dam. Cavities were prepared -by high-speed hand piece and burs number 330 in the utmost conservative manner to provide minimal destruction of treated molars shown in Figure (2). When soft carious lesions were encountered, round bur mounted in low-speed handpiece was used to eradicate them. Regarding the depth of the cavities, it was standardized and extended to dentin, deep cavities were protected with cavity liner. Moreover, the mesiodistal and buccolingual cavity widths did not exceed 3-6 $\mathrm{mm}$ and were classified as medium sized cavities. ${ }^{(31)}$

Both light cured Fuji II and packable Fuji IX (GC, Europe) were prepared according to the manufacturers' instructions, and thereby placed into the prepared cavities shown in Figures $(2 \& 3)$. Ball burnisher was used to ensure adaptation of the material to the whole cavity as well as to smooth the materials occlusally. Finally, occlusion was checked and adjusted if needed.

\section{Follow up intervals:}

To evaluate success and clinical performance of treated primary molars; patients were clinically examined after 3, 6,9 and 12 months postoperatively according to the set criteria of evaluation. 


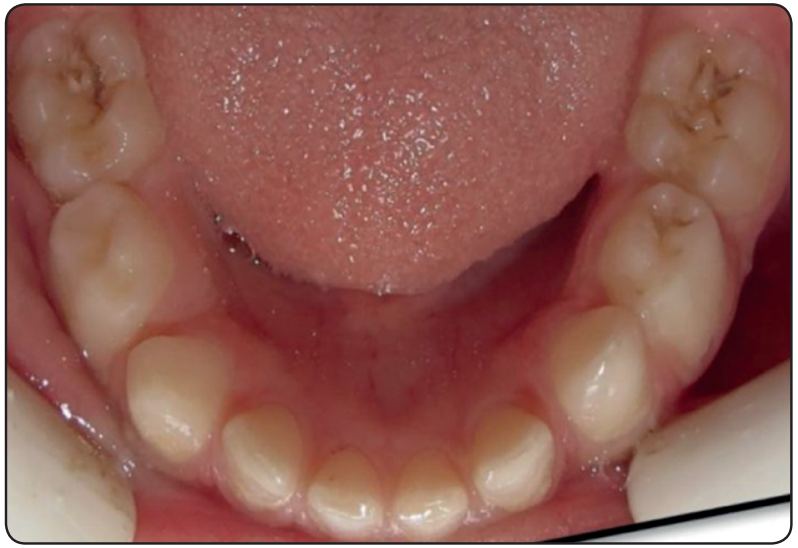

Fig. (1): Preoperative clinical picture showing bilateral restorable decayed second primary molars with simple occlusal decay.

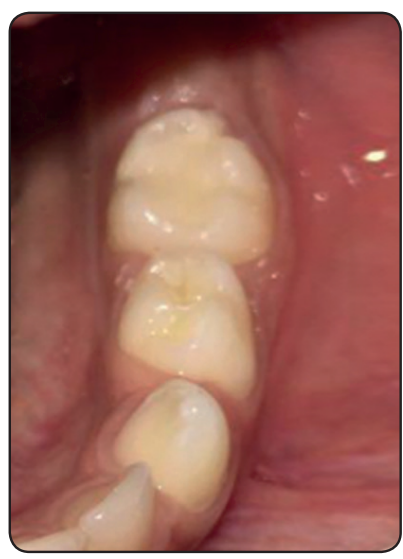

Fig. (3): Postoperative clinical picture showing restoring lower second primary molar restored by Fuji II.

\section{Criteria of evaluation:}

Treatment was considered clinically successful according to United States Public Health Services (USPHS) evaluation criteria and rating system of clinical characteristics of restorations shown in Figure (5). ${ }^{(32)}$

\section{Statistical Analysis}

Qualitative data were presented as frequencies and percentages. Wilcoxon signed-rank test was used for comparisons between the two groups. Friedman's test followed by Dunn's test was

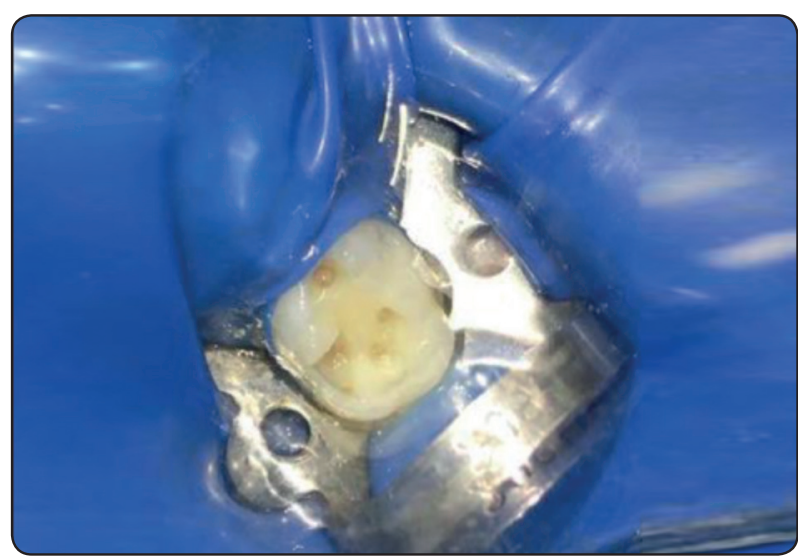

Fig. (2): Clinical picture showing second primary molars after isolation with rubber dam and minimal caries removal.

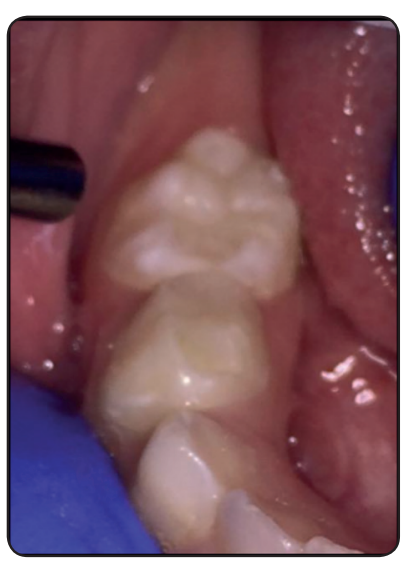

Fig. (4): Postoperative clinical picture showing restoring lower second primary molar restored by Fuji IX.

\begin{tabular}{|c|c|c|}
\hline Clinical characteristics & Category of rating & Evaluation criteria \\
\hline Marginal adaptetion & $\begin{array}{l}\text { A } \\
\text { B } \\
\text { C } \\
\text { D }\end{array}$ & $\begin{array}{l}\text { No catch or visible cridencc of a cervicc along the margin } \\
\text { A small catch. crevice or ditch but dentin or cement base is not exposed } \\
\text { Dentin or cement base is exposed } \\
\text { Mobile restoration, fractured or missing in part or total }\end{array}$ \\
\hline Anatomic form & $\begin{array}{l}\text { A } \\
\text { B } \\
\text { C }\end{array}$ & $\begin{array}{l}\text { Restoration contour is continuous with existing anatomic form } \\
\text { Restoration is under contoured, restorative material discontinuous with the existing } \\
\text { anatomic form but loss of matcrial not sufficicnt to cxposc dentin or basc } \\
\text { Loss of material to the extent that dentin or base is exposed }\end{array}$ \\
\hline Secondary canics & $\begin{array}{l}\text { A } \\
\text { B }\end{array}$ & 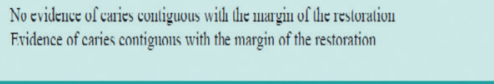 \\
\hline Margin discoloration & $\begin{array}{l}\text { A } \\
B\end{array}$ & $\begin{array}{l}\text { No discoloration penetrated along the margin of the material in a pulpal direction } \\
\text { Discoloration penctratcd along the margin of the matcrial in a pulpal dircetion }\end{array}$ \\
\hline
\end{tabular}

Fig. (5): The evaluation criteria and rating system of clinical characteristics of restorations. 
used to study the changes by time in each group. The significance level was set at $\mathrm{P} \leq 0.05$. Statistical analysis was performed with IBM ${ }^{\circledR}$ SPSS ${ }^{\circledR}$ Statistics Version 20 for Windows.

\section{RESULTS}

\section{Demographic data}

The present study was conducted on 38 subjects; 18 boys $(47.4 \%)$ and 20 girls $(52.6 \%)$. The mean \pm standard deviation values for age were $5.7 \pm 0.8$ years old with a minimum of 5 and a maximum of 7 years old.

During the follow up period of the current study drop out of some cases had been noticed with a total number of 7 cases. So, the authors completed this study with 31 instead of 38 cases.

\section{Clinical Performance data}

The clinical characteristics of the two investigated materials (Fuji II and Fuji IX) were assessed in terms of; marginal adaptation, anatomic form, secondary caries and marginal discoloration.

\section{Marginal adaptation}

Comparing molars restored by Fuji II and Fuji IX, there was no statistically significant difference between marginal adaptation scores after 3, 6 and 9 months postoperatively. A statistically significant difference was noted after 12 months. Molars restored by Fuji II showed less prevalence of Score B and Score C than Fuji IX while score A showed nearly the same prevalence with both Fuji II and Fuji IX.

As regards the change by time, there was a statistically significant change in marginal adaptation scores in molars restored by Fuji II and Fuji IX. For both materials, there was an increase in prevalence of Score B after 6, 9 and 12 months. Score C was not found except after 12 months postoperatively.
TABLE (1): Frequencies (n), percentages (\%) and results of Wilcoxon signed-rank test for comparison between marginal adaptation scores in molars treated by both materials and Friedman's test for the changes by time within each material.

\begin{tabular}{|c|c|c|c|c|c|}
\hline \multirow{2}{*}{ Time } & \multicolumn{2}{|c|}{ Fuji II } & \multicolumn{2}{|c|}{ Fuji IX } & \multirow{2}{*}{$\begin{array}{c}P \text {-value } \\
\text { (Between } \\
\text { materials) }\end{array}$} \\
\hline & $\mathrm{n}$ & $\%$ & $\mathrm{~N}$ & $\%$ & \\
\hline \multicolumn{5}{|l|}{3 months } & \multirow[b]{2}{*}{0.317} \\
\hline Score A & $36 / 36$ & 100 & $35 / 36$ & 97.2 & \\
\hline Score B & $0 / 36$ & 0 & $1 / 36$ & 2.6 & \\
\hline \multicolumn{5}{|l|}{6 months } & \multirow[b]{2}{*}{0.157} \\
\hline Score A & $33 / 35$ & 94.3 & $31 / 35$ & 88.6 & \\
\hline Score B & $2 / 35$ & 5.7 & $4 / 35$ & 11.4 & \\
\hline \multicolumn{5}{|l|}{9 months } & \multirow[b]{2}{*}{0.317} \\
\hline Score A & $28 / 33$ & 84.8 & $26 / 33$ & 78.8 & \\
\hline Score B & $5 / 33$ & 15.2 & $7 / 33$ & 21.2 & \\
\hline \multicolumn{5}{|l|}{12 months } & \multirow{3}{*}{$0.025^{*}$} \\
\hline Score A & $23 / 31$ & 60.5 & $19 / 31$ & 61.3 & \\
\hline Score B & $7 / 31$ & 18.4 & $10 / 31$ & 32.3 & \\
\hline Score C & $1 / 31$ & 2.6 & $2 / 31$ & 6.5 & \\
\hline $\begin{array}{c}P \text {-value (With- } \\
\text { in material) }\end{array}$ & \multicolumn{2}{|c|}{$0.001 *$} & \multicolumn{2}{|c|}{$<0.001 *$} & \\
\hline
\end{tabular}

*: Significant at $P \leq 0.05$.

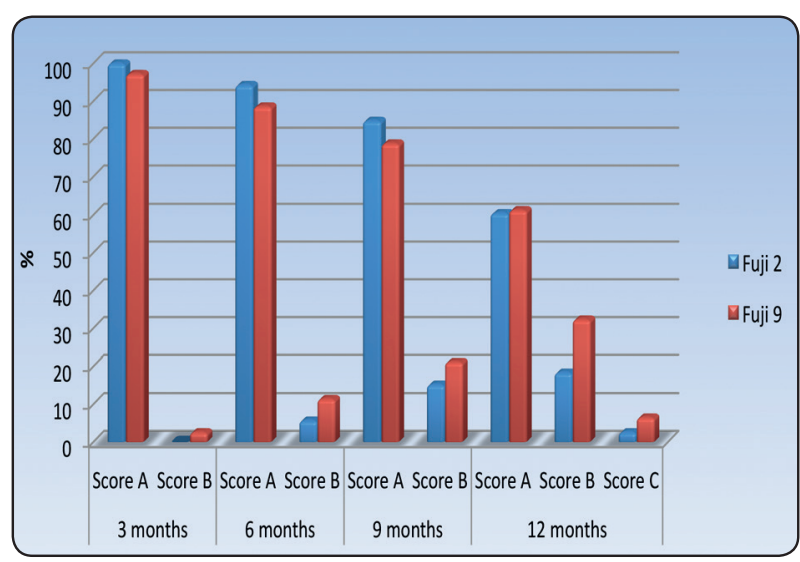

Fig. (6): Bar chart representing marginal adaptation scores in the two materials. 


\section{Anatomic form}

After 3 and 6 months postoperatively, there was a statistically significant difference between anatomic form scores in the two materials. Fuji II showed less prevalence of Score B than Fuji IX. After 9 and 12 months postoperatively, there was also a statistically significant difference between anatomic form scores in the two materials. Fuji II showed less prevalence of Score B and no prevalence of Score C compared to Fuji IX.

As regards the change by time, there was a statistically significant change in anatomic form scores of each group. In both groups, there was an increase in prevalence of Score B after 6,9 and 12 months.

TABLE (2): Frequencies (n), percentages (\%) and results of Wilcoxon signed-rank test for comparison between anatomic form scores in the two materials and Friedman's test for the changes by time within each material.

\begin{tabular}{|c|c|c|c|c|c|}
\hline \multirow{2}{*}{ Time } & \multicolumn{2}{|c|}{ Fuji II } & \multicolumn{2}{|c|}{ Fuji IX } & \multirow{2}{*}{$\begin{array}{c}P \text {-value } \\
\text { (Between } \\
\text { materials) }\end{array}$} \\
\hline & $\mathrm{N}$ & $\%$ & $\mathrm{~N}$ & $\%$ & \\
\hline \multicolumn{5}{|l|}{3 months } & \multirow[b]{2}{*}{$0.046^{*}$} \\
\hline Score A & $35 / 36$ & 97.2 & $31 / 36$ & 86.1 & \\
\hline Score B & $1 / 36$ & 2.8 & $5 / 36$ & 13.9 & \\
\hline \multicolumn{5}{|l|}{6 months } & \multirow[b]{2}{*}{$0.025^{*}$} \\
\hline Score A & $32 / 35$ & 91.4 & $27 / 35$ & 77.1 & \\
\hline Score B & $3 / 35$ & 8.6 & $8 / 35$ & 22.9 & \\
\hline \multicolumn{5}{|l|}{9 months } & \multirow[b]{2}{*}{$0.005^{*}$} \\
\hline Score A & $25 / 33$ & 75.8 & $18 / 33$ & 54.5 & \\
\hline Score B & $8 / 33$ & 24.2 & $14 / 33$ & 42.4 & \\
\hline Score C & $0 / 33$ & 0 & $1 / 33$ & 3 & \\
\hline \multicolumn{5}{|l|}{12 months } & \multirow{3}{*}{$<0.001 *$} \\
\hline Score A & $21 / 31$ & 67.7 & $8 / 31$ & 25.8 & \\
\hline Score B & $10 / 31$ & 32.3 & $22 / 31$ & 71 & \\
\hline Score C & $0 / 31$ & 0 & $1 / 31$ & 3.2 & \\
\hline $\begin{array}{c}P \text {-value (With- } \\
\text { in material) }\end{array}$ & \multicolumn{2}{|c|}{$<0.001 *$} & \multicolumn{2}{|c|}{$<0.001 *$} & \\
\hline
\end{tabular}

*: Significant at $P \leq 0.05$.

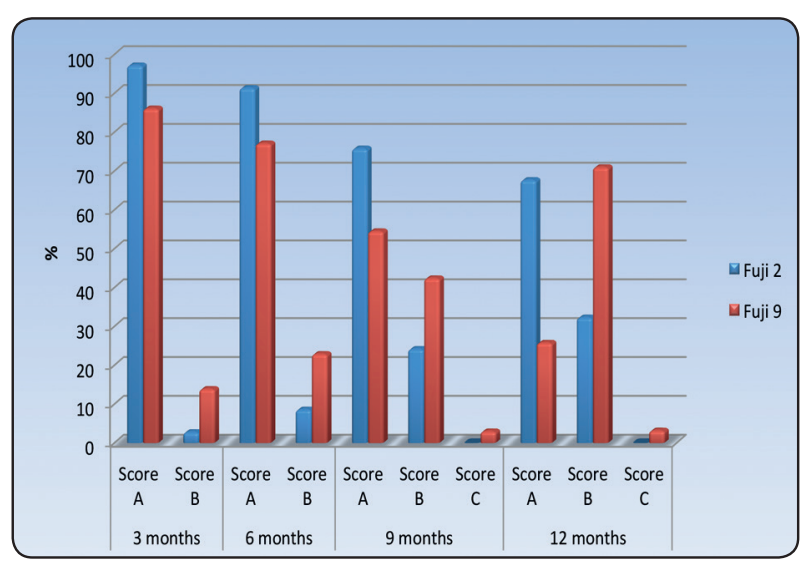

Fig. (7): Bar chart representing anatomic form scores in the two materials.

\section{Secondary caries}

After 3 and 6 months, all cases had score A. After 9 months, there was no statistically significant difference between secondary caries scores in the two materials. After 12 months, there was a statistically significant difference between secondary caries scores in the two materials. Fuji II showed less prevalence of Score B than Fuji IX.

As regards the change by time, there was a statistically significant change in secondary caries scores of each material. In both materials, there was no change in scores from 3 to 6 months followed by an increase in prevalence of Score B after 9 and 12 months.

TABLE (3): Frequencies (n), percentages (\%) and results of Wilcoxon signed-rank test for comparison between secondary caries scores in the two materials and Friedman's test for the changes by time within each material.

\begin{tabular}{|l|c|c|c|c|c|}
\hline \multirow{2}{*}{ Time } & \multicolumn{2}{|c|}{ Fuji II } & \multicolumn{2}{c|}{ Fuji IX } & \multirow{2}{*}{$\begin{array}{c}\text {-value } \\
\text { (Between } \\
\text { materials) }\end{array}$} \\
\cline { 2 - 4 } & $\mathrm{N}$ & $\%$ & $\mathrm{~N}$ & $\%$ & \multirow{2}{|l}{} \\
\hline 3 months \\
\hline Score A & $36 / 36$ & 100 & $36 / 36$ & 100 & 1.000 \\
\hline 6 months & 1.000 \\
\hline Score A & $35 / 35$ & 100 & $35 / 35$ & 100 & \\
\hline
\end{tabular}




\begin{tabular}{|c|c|c|c|c|c|}
\hline \multirow{2}{*}{ Time } & \multicolumn{2}{|c|}{ Fuji II } & \multicolumn{2}{|c|}{ Fuji IX } & \multirow{2}{*}{$\begin{array}{c}P \text {-value } \\
\text { (Between } \\
\text { materials) }\end{array}$} \\
\hline & $\mathrm{N}$ & $\%$ & $\mathrm{~N}$ & $\%$ & \\
\hline \multicolumn{5}{|l|}{9 months } & \multirow[b]{2}{*}{0.564} \\
\hline Score A & $31 / 33$ & 93.9 & $30 / 33$ & 90.9 & \\
\hline Score B & $2 / 33$ & 6.1 & $3 / 33$ & 9.1 & \\
\hline \multicolumn{5}{|l|}{12 months } & \multirow{3}{*}{$0.046^{*}$} \\
\hline Score A & $27 / 31$ & 87.1 & $23 / 31$ & 74.2 & \\
\hline Score B & $4 / 31$ & 12.9 & $8 / 31$ & 25.8 & \\
\hline $\begin{array}{c}P \text {-value (With- } \\
\text { in material) }\end{array}$ & \multicolumn{2}{|c|}{$0.024 *$} & \multicolumn{2}{|c|}{$<0.001 *$} & \\
\hline
\end{tabular}

*: Significant at $P \leq 0.05$.

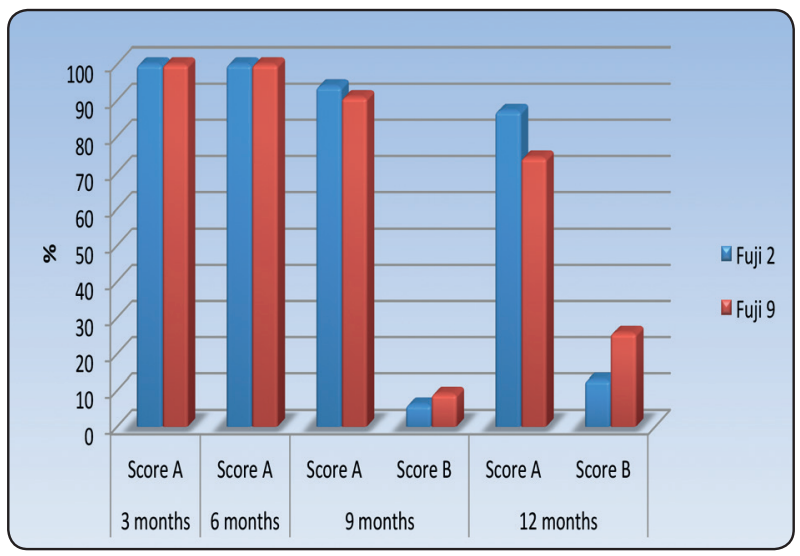

Fig. (8): Bar chart representing secondary caries scores in the two materials.

\section{Marginal discoloration}

After and 6 months, there was no statistically significant difference between marginal discoloration scores in the two materials. After 6 and 12 months, there was a statistically significant difference between marginal discoloration scores in the two materials. Fuji II showed less prevalence of Score B than Fuji IX.

As regards the change by time, there was a statistically significant change in marginal discoloration scores of each material. In both materials, there was an increase in prevalence of Score B after 6,9 and 12 months.
TABLE (4): Frequencies (n), percentages (\%) and results of Wilcoxon signed-rank test for comparison between marginal discoloration scores in the two materials and Friedman's test for the changes by time within each material.

\begin{tabular}{|c|c|c|c|c|c|}
\hline \multirow[t]{2}{*}{ Time } & \multicolumn{2}{|c|}{ Fuji II } & \multicolumn{2}{|c|}{ Fuji IX } & \multirow{2}{*}{$\begin{array}{c}P \text {-value } \\
\text { (Between } \\
\text { materials) }\end{array}$} \\
\hline & $\mathrm{n}$ & $\%$ & $\mathrm{~N}$ & $\%$ & \\
\hline \multicolumn{5}{|l|}{3 months } & \multirow[b]{2}{*}{0.317} \\
\hline Score A & $36 / 36$ & 100 & $35 / 36$ & 97.2 & \\
\hline Score B & $0 / 36$ & 0 & $1 / 36$ & 2.8 & \\
\hline \multicolumn{5}{|l|}{6 months } & \multirow[b]{2}{*}{0.317} \\
\hline Score A & $30 / 35$ & 85.7 & $29 / 35$ & 82.9 & \\
\hline Score B & $5 / 35$ & 14.3 & $6 / 35$ & 17.1 & \\
\hline \multicolumn{5}{|l|}{9 months } & \multirow[b]{2}{*}{$0.046^{*}$} \\
\hline Score A & $25 / 33$ & 75.8 & $21 / 33$ & 63.6 & \\
\hline Score B & $8 / 33$ & 24.2 & $12 / 33$ & 36.4 & \\
\hline \multicolumn{5}{|l|}{12 months } & \multirow{3}{*}{$0.003^{*}$} \\
\hline Score A & $21 / 31$ & 67.7 & $12 / 31$ & 38.7 & \\
\hline Score B & $10 / 31$ & 32.3 & $19 / 31$ & 61.3 & \\
\hline $\begin{array}{c}P \text {-value (With- } \\
\text { in material) }\end{array}$ & \multicolumn{2}{|c|}{$<0.001 *$} & \multicolumn{2}{|c|}{$<0.001 *$} & \\
\hline
\end{tabular}

*: Significant at $P \leq 0.05$.

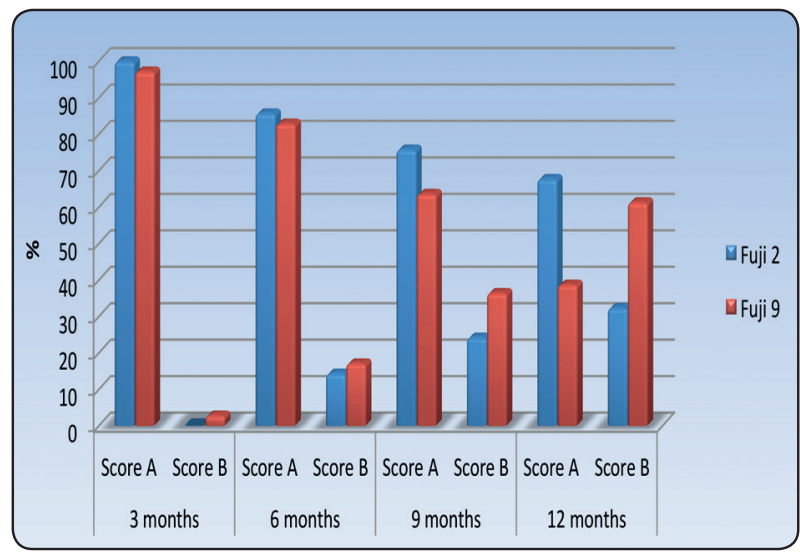

Fig. (9): Bar chart representing marginal discoloration scores in two materials. 


\section{DISCUSSION}

To benefit from its merits, glass ionomer cements are commonly utilized in pediatric dentistry. Technologies are continuously modifying aesthetic restorations and trails are boundless in order to benefit from the best possible advantages of such materials. ${ }^{(33)}$ From this perspective, the present study aimed to assess the clinical performance and success of different versions of glass ionomers.

Split mouth technique was employed in the current study in order to assess the investigated materials under the same clinical conditions and oral environment as well as to standardize the dietary habits and oral hygiene health practices. This was in agreement with studies performed by Riordan \& Fitzgerald $1994{ }^{(34)}$ as well as Daou et al., 2008. ${ }^{(35)}$

Inclusion criteria entailed that treated patients were 5-7 years old in order to be cooperative and away from the age of physiologic exfoliation of the chosen primary molars. Among the treated 38 subjects; 18 were boys (47.4\%) and 20 were girls $(52.6 \%)$.

All selected children had at least bilateral matched occlusal carious lesions affecting second primary molars indicated for restorative treatment. The choice of the second primary molars in the current study was based on the fact that they have a long life-span in comparison to the first primary molars which exfoliate earlier and usually these molars are affected by proximal decay. Further, all treated patients were selected from outpatient clinics of Pediatric Dentistry and Dental Public Health Department- Faculty of Dentistry, thus represented the same socioeconomic status and possibly similar oral health statuses and dental care.

Though follow-up period of 12 months postoperatively might be considered a short time interval for assessment of treatment in permanent dentition, this might be fairly beneficial in tracking offered treatment in primary dentition. This is because of the short life span of primary teeth and their restorations, in addition to giving the chance for early detection of any changes -such as secondary caries- to be revealed during this follow up period. ${ }^{(35,36)}$

During the follow up period the authors noticed dropout of a total of 7 cases 2 of them at 3 months, one at 6,2 at 9 and 2 at 12 months, so the current study was completed with 31 instead of 38 cases. The authors noticed that there was a failure of communication with them. In our opinion dropout may be attributed to difficulty in transportation or the parents cannot take a day off work to bring their child for follow up which may be a financial burden for them. Moreover, some patients once they are relived from pain they have no interest to attend to the hospital again for follow up.

Mean \pm standard deviation values for age of treated patients were $5.7 \pm 0.8$ years old with a minimum of 5 and a maximum of 7 years old.

Assessment of treated molars was performed using USPHS evaluation criteria and rating system of clinical characteristics of restorations. ${ }^{(31)}$ This rating was utilized in this study because it offers possible outcomes that might be encountered during the follow up period. In addition, it categorizes each outcome into several scores according to quality revealed during assessment. Consequently, following USPHS criteria, the clinical characteristics of investigated materials -Fuji II and Fuji IXwere assessed in terms of; marginal adaptation, anatomic form, secondary caries and marginal discoloration.

Regarding the results of marginal adaptation, score A was recorded in $60.5 \%$ and $61.3 \%$ in molars restored by Fuji II and Fuji IX respectively (Table 1 and Figure 6). This came in contrast to results revealed by Yilmaz et al., $2006{ }^{(37)}$ and Daou et al., $2008^{(35)}$ in which A score presented $97.1 \%$ for class I restorations using Fuji IX in the former study and $91 \%$ in the latter study when Fuji II was used and assessed after 12 months postoperatively. This difference in success rates might be due to high caries burden in patients treated in the current 
study. As high bacterial load due to presence of numerous carious lesions might affect success of the performed restorations and their longevity. ${ }^{(38)}$

Regarding the results of anatomic form, score A was noted in $67.7 \%$ and $25.8 \%$ in molars restored by Fuji II and Fuji IX respectively (Table 2 and Figure 7). This was in agreement with the results of Folwaczny et al., $200{ }^{(39)}$ where $58.8 \%$ of Fuji II fillings demonstrated a perfect anatomical form. Possibly, such close results might be attributed to usage of encapsulated systems which provide invariable reliable mixtures with consistent stability.

Regarding the results of secondary caries, score A was shown in $87.1 \%$ and $74.2 \%$ among Fuji II and Fuji IX restorations respectively (Table 3 and Figure 8), whereas score B (secondary caries) was noted in $12.9 \%$ and $25.8 \%$ of Fuji II and Fuji IX restorations respectively after 12 months. Such results disagreed with the results of Yilmaz et al., $2006^{(37)}$ in which the recorded secondary caries was $2.9 \%$ when Fuji IX was used. Further, the results of this study disagreed likewise with study conducted by Daou et al., $2008{ }^{(35)}$ in which 3\% and $12 \%$ of the evaluated restorations had evidence of secondary caries when restored by Fuji II and Fuji IX respectively. This might be explained by difference in restoration size after caries removal because larger restorations provide greater surface area subjected to recurrent decay and this might had been encountered in this study.

Regarding the results of marginal discoloration, it was noted in $32.3 \%$ and $61.3 \%$ when Fuji II and Fuji IX were used respectively (Table 4 and Figure 9). In other words, score A (absence of marginal discoloration) was noted in $67.7 \%$ and $38.7 \%$ when Fuji II and Fuji IX were used respectively. This was in contrast to results of Folwaczny et al., $200{ }^{(39)}$ and Yilmaz et al., $2006^{(37)}$ in which B score (marginal discoloration) was noted in $17.6 \%$ when Fuji II was used in the former study and $14.7 \%$ was revealed when Fuji IX was applied in the latter study. In addition, the results of this study disagreed with results of study conducted by Daou et al., $2008^{(35)}$ where no marginal discoloration was observed when Fuji II was used after 12 months. In our opinion, marginal discoloration might be due to presence of minute cracks within the tested material or thin enamel at the discolored areas.

\section{CONCLUSION}

According to the results of this study we can conclude that:

1- Fuji II and Fuji IX showed comparable marginal adaptation.

2- Fuji II restorations showed better results regarding anatomic form, secondary caries and marginal discoloration when compared to Fuji IX.

\section{RECOMMENDATIONS}

1- Resin modified GIC (Fuji II) can be recommended as a restorative material in simple occlusal caries in primary molars.

2- Prolonged follow up period (more than one year) is recommended to study the performance of the materials over an extended period of time.

\section{REFERENCES}

1- Dye, B. A., Arevalo, O., \& Vargas, C. M. Trends in paediatric dental caries by poverty status in the United States, 1988-1994 and 1999-2004. Int J Paediatr Dent 2010; 20(2), 132143. doi: 10.1111/j.1365-263X.2009.01029.x

2- Casamassimo, P. S., Thikkurissy, S., Edelstein, B. L., \& Maiorini, E. Beyond the dmft: the human and economic cost of early childhood caries. J Am Dent Assoc 2009; 140(6): 650-657.

3- Chi, D. L., Rossitch, K. C., \& Beeles, E. M. Developmental delays and dental caries in low-income preschoolers in the USA: a pilot cross-sectional study and preliminary explanatory model. BMC Oral Health 2013; 13, 53. doi: 10.1186/1472-6831-13-53.

4- American Academy of Pediatric Dentistry (AAPD) Guideline on Pediatric Restorative Dentistry. Retrieved December 30, 2013. http://www.aapd.org/media/Policies_ Guidelines/G_Restorative.pdf. 
5- Bernardo, M., Luis, H., Martin, M. D., Leroux, B. G., Rue, T., Leitao, J., \& DeRouen, T. A. Survival and reasons for failure of amalgam versus composite posterior restorations placed in a randomized clinical trial. J Am Dent Assoc 2007; 138(6): 775-783.

6- Hickel R, Manhart J. Glass - ionomers and compomers in pediatric dentistry. In: Davidson CL, Mjo “r IA, editors. Advances in glass - ionomer cements. Leipzig: Quintessence Publishing; 1999. p. 201-26.

7- Qvist V. Longevity of restorations in primary teeth. In: Hugoson A, Falk M, Johansson S, editors. Consensus conference on caries in the primary dentition and its clinical management. Stockholm: Fo “rlagshuset Gothia; 2002. p. 69-83.

8- Berg, J. H. The continuum of restorative materials in pediatric dentistry--a review for the clinician. Pediatr Dent 1998; 20(2): 93-100.

9- Wilson AD, Kent BE. A new translucent cement for dentistry. Br Dent J 1972; 132: 133-135.

10- Aboush YEY, Torabzadeh H. Floride release from toothcolored restorative materials: A month report. J Can Dent Assoc 2001; 64 (561): 64-68.

11- Anusavice KJ. Physical Properties of Dental Materials. In: Anusavice KJ eds. Phillips' Sciences of Dental Materials. 10th ed. Philadelphia: W.B. Saunders Co; 1996: 33-47.

12- Chung KH. The properties of metal-reinforced glass-ionomer materials. J Oral Rehabil 1993; 20: 79-87.

13- Craig RG, Powers JM, Wataha JC. Dental Materials Properties and Manipulation. 7th ed. St Louis: CV Mosby Co; 2000; 57-78.

14- Dennison JB, Craig RG. Preventive Materials. In: Craig RG, Powers JM eds. Restorative Dental Materials11th ed. St Louis: Mosby Co; 2002: 199-230.

15- Mc Lean JW. Cement cements. J Am Dent Assoc 1990; 120: 43-47.

16- Mount GJ. Clinical Placement of modern glass-ionomer cements. Quintessence Int 1993; 24: 99-107.

17- Östlund J, Möller K, Koch G. Amalgam, composite resin and glass-ionomer cement in class II restorations in primary molars. A three-year clinical evaluation. Swed Dent J 1992; 16: 81-86.

18- Weidlich P, Miranda LA, Maltz M, et al. Fluoride release and uptake from glass-ionomer cements and composite resin. Braz Dent J 2000; 11: 89-96.
19- Simmons JJ. The miracle mixture glass-ionomer and alloy powder. Texas Dent J 1983; 1: 6-13.

20- Bilgin Z, Dogruluk G, Aras S. Geleneksel bir cam ionomer siman ve amalgamla olusturulan restoratif simanın 6 aylık klinik sonuçları ile bazı fizik-mekanik özelliklerinin degerlendirilmesi. Atatürk Univ. Dis Hek Fak Derg 1993; 20: 401-407.

21- Mc Lean JW. Alternatives to amalgam alloys. Br Dent J 1984; 157: 432-433.

22- Mc Lean JW, Gasser O. Glass-cement cements. Quintessence Int 1985; 5: 333-343.

23- Kilpatrick NM, Murray JJ, McCabe JF. The use of a reinforced glass-ionomer cement for the restoration of primary molars: A clinical trial. Br Dent J 1995; 179: 175-179.

24- Frankenberger R, Krämer N, Grof A, et al. Cyclic fatigue of glass ionomers and compomers (English Abstract). Dtsch Zahnärztl 1999; 54:269-271.

25- Krämer N, Pelka M, Kautetzky P, et al. Wear resistance of compomers and viscous glass-ionomer cements (English Abstract). Dtsch Zahnärtzl Z 1996; 52: 186-189.

26- Williams JA, Billington RW, Pearson GJ. The comparative strengths of commercial glass-ionomer cements with and without metal additions. Br Dent J 1992; 172: 279-282.

27- Yilmaz Y, Belduz N, Kocogullari E, et al. Çesitli restoratif cam ionomer materyallerin marjinal sirt dayanikliliginin degerlendirilmesi: Bir in vitro çalisma. Atatürk Univ Dis Hek Fak Derg 2002; 12: 14-21.

28- Lo ECM, Luo Y, Fan MW, et al. Clinical investigation of two glass-ionomer restoratives used with the atraumatic restorative treatment approach in China: Two-year results. Caries Res 2001; 35: 458- 463.

29- Frankenberger R, Sindel J, Krämer N. Viscous glass-ionomer cements: A new alternative to amalgam in the primary dentition? Quintessence Int 1997; 28: 667-676.

30- Hubel S, Mejare I. Conventional versus resin-modified glass-ionomer cement for Class II restorations in primary molars. A 3-year clinical study. Int J Paediatr Dent. 2003 Jan; 13 (1): 2-8.

31- Mufti AS. Clinical Efficacy of The Conventional Glass Ionomer Cement and Resin Modified Glass Ionomer Cement in Primary Molars. J Ayub Med Coll Abbottabad 2014; 26 (4): 587-590. 
32- Ryge G. Clinical criteria. Int Dent J 1980; 30: 347-358.

33- Nandana KL, Sai Sankar AJ, Manoj Kumar MG, Naveen K, Pranitha K, Manjula BS. Comparative evaluation of microleakage using three variables of glass-ionomer cement in primary and permanent teeth: An in vitro study. J Interdiscip Dentistry 2016; 6:110-115.

34- Riordan P J, Fitzgerald P E: Outcome measures in split mouth caries trials and their statistical evaluation. Community Dent Oral Epidemiol 1994; 22: 192-197.

35- Daou MH, Tavernier B, Meyer JM. Clinical evaluation of four different dental restorative materials: one-year results. Schweiz Monatsschr Zahnmed 2008;118 (4):290-295.

36- Forss H, Widström E. The post amalgam era: a selection of materials and their longevity in the primary and young per- manent dentitions. Int J Paediatr Dent 2003; 13: 158-164.

37- Yilmaz Y, Eyuboglu Ö, Kocogullari ME, Belduz M. A One-Year Clinical Evaluation of a High-Viscosity Glass Ionomer Cement in Primary Molars. J Contemp Dent Pract 2006 February; 7(1): 71-78.

38- McCracken MS, Gordan VV, Litaker MS, Funkhouser E, Fellows J, Shamp D, Qvist V, Meral JS, Gilbert GH. A 24-month evaluation of amalgam and resin-based composite restorations. Journal of the American Dental Association 2013;144(6):583-593.

39- Folwaczny M, Loher C, Kunzelmann A, Hinkel R. ToothColored Filling Materials for the Restoration of Cervical Lesions: A 24-Month Follow-Up Study. Operative Dentistry July-August 2000; 25(4): 249-352. 